\title{
The relationship between soil chemical properties and phytochemical contents of non-centrifugal cane brown sugar in Thailland
}

\author{
Kanyaphat Meerod ${ }^{1}$, Monthana Weerawatanakorn $^{1^{*}}$ and Wanwisa Pansak ${ }^{2}$ \\ ${ }^{1}$ Department of Agro-Industry, Naresuan University, 99 Moo 9, Tha Pho, Phitsanulok 65000, Thailand \\ ${ }^{2}$ Department of Agricultural Science Faculty of Agriculture Natural Resources and Environment, Naresuan \\ University, 99 Moo 9, Tha Pho, Phitsanulok , 65000, Thailand
}

*Corresponding author: monthanac@nu.ac.th

\begin{abstract}
In Thailand, NCS products from sugarcane are traditionally produced by the evaporation of raw cane juice obtained from a pressing machine. NCS products enhance flavor and supply both energy and nutritional value through the vitamins, minerals and bioactive compounds which occur naturally in sugarcane produced without molasses removal. Soil quality and choice of cane cultivar affect the nutraceutical components of brown cane sugar products grown in diverse areas. Differences in nutraceutical components of NCS products obtained by traditional processes were investigated form sugarcane planted in two different areas of Sukhothai Province, with varied soil qualities based on the same cane variety (LK-92-11). The soil classification was carried out according to the Staff Soil Survey (2014) and classified as Aquic Haplustalfs and Aeric Endoaquepts soil types. NCS products from sugarcane planted in Aquic Haplustalfs contained high nutraceuticals and antioxidant activities compared with sugarcane planted in Aeric Endoaquepts. EC and potassium content of the soils showed significant negative correlation with policosanols, total phenolics, total flavonoid contents, and antioxidant activities of the NCS products. Pearson's correlation indicated that higher electrical conductivity and potassium content of the soils were attributable to lower amounts of policosanols, total phenolics, and total flavonoid contents as well as antioxidant activities. We suggested that electrical conductivity and potassium content of soil should be concerned and monitored to obtain high level of nutraceutical of NCS product made from sugarcane.
\end{abstract}

Keywords: Sugarcane; nutraceuticals; soil quality; brown sugar products; antioxidant.

Abbreviations: NCS_non-centrifugal sugar; EC_Electrical conductivity; PC_Policosanols.

\section{Introduction}

Sugarcane (Saccharum officinarum L.) is the most important feedstock of sugar production since it provides nearly $70 \%$ of the sugar consumed worldwide (Feng et al., 2014). Increased health risks from excessive intake of refined sugar have sparked global interest for healthier sugar substitutes (García et al., 2017). Brown cane sugar is the most appealing commercial substitute because of its various biological functions with beneficial activities on human health (Jaffe, 2012; Asikin et al., 2014). NCS product or brown cane sugar is available in many countries under different names as Gur (India), Panela (Mexico and South America), Jaggery (Africa), Rapadura (Brazil), Kokuto or Kurozato (Japan), and Naam Taan Oi (Thailand) (Weerawatanakorn et al., 2016). According to the FAO (1994), non-centrifugal sugar product is the technical term for brown cane sugar. NCS is traditionally produced by dehydrating the sugarcane juice without molasses removal. This significantly reduces the loss of natural minerals, vitamins, and phytochemicals (Weerawatanakorn et al., 2016).

The unique brown color of NCS is generated by chemical reactions involving non-enzymatic browning (Maillard reaction) and caramellization (Takahashi et al., 2016), while the presence of phenolic compounds, mainly phenylpropanoids and flavonoids, also plays an important role in brown color generation (Duarte-Almeida et al., 2007; Iqbal et al., 2017). The NCS contains nutrients including amino acids, minerals, vitamins, and bioactive compounds such as phenolic acids (chlorogenic, caffeic and coumaric acids), flavonoids (derivatives of tricin, apigenin and luteolin) (Takara et al., 2002), and long-chain alcohols, known as policosanols (PC). The various beneficial biological functions regarding human health have been reported for NCS products including anti-cariogenic, antitoxic-cytoprotective, anti-carcinogenic, and antioxidant effects (Payet et al., 2005; Jaffe, 2012). Among several flavonoid derivatives isolated from NCS extracts, tricin showed in vitro antiproliferative activity against several human cancer cell lines (Duarte-Almeida et al., 2007) and may be considered safe enough for clinical development as a cancer chemopreventive agent (Verschoyle et al., 2006). Other interesting components in NCS including PC and long-chain aldehydes (policosanals) have also been reported. PC comprise a group of long-chain (C22-C34) aliphatic primary alcohols that possess cholesterol and lipid-reducing properties (Weerawatanakorn et al., 2016). They are mainly found in sugarcane wax, especially in the rind of the stalk (Nuissier et al., 2002; Purcell et al., 2005) and remain in brown cane sugar if production lacks the refining step (Asikin et al., 2008). The 
PC content of Japanese NCS products, known there as "Kokuto", and Thai NCS, known as Nam Tann Oi ranged from 7.0-85.7 and 2.6-3.7 mg/100g, respectively (Asikin et al., 2008; Weerawatanakorn et al., 2016).

Thailand is among the world's leading sugarcane producers and refined sugar exporters (FAO 2017). Sugarcane is a significant Thai economic plant (Prasara et al., 2016) and crop sustainability must be maintained. Soil quality is an important criterion to realize yield and quality of sugarcane and cane products (Cherubin et al., 2016). Many factors including genotype, ontogeny, and environment affect amounts and types of phytochemicals in a plant. Few information have been made to link soil properties to phytochemical contents in crops and final food products (Zhao et al., 2006). Therefore, the effect of soil quality variation in two different sub-districts was assessed regarding the nutraceutical contents including PC, tricin, phenolic compounds and antioxidant activity of sugar products produced by traditional methods of evaporation in an open pan. Soil characteristics, physicochemical properties, antioxidant activity, policosanol and tricin contents of NCS products (Nam Tann Oi) were analyzed to determine any significant relationships.

\section{Results and Discussion}

\section{Chemical properties of soil in sugarcane field}

Two sugarcane field areas in Sukhothai Province were selected to analyze soil qualities. The first area was Koh Ta Liang Sub-district, Srisomrong District (SR) and the second was Yanyaow Sub-district, Sawankhalok District (SK). Following the Soil Survey Division Staff, (2014), soil from the first area was classified as Aeric Endoaquepts. The soils were composed of very deep clay that formed in flood basin deposits on alluvial plains. The study site was a flat plain with waterlogged soil condition during the rainy season. It had a clay texture with black or gray surface color. Subsoil color was light brown to brown with mottles of yellowish brown, reddish brown and red with limestone, iron, and manganese (Fig 1b.). Based on chemical properties (Table 1.), the top soil (0-20 cm depth) had an organic matter content of $1.7 \%$, a total $\mathrm{N}$ content of $0.05 \%$, an available $\mathrm{P}$ (Bray II) content of $3.97 \mathrm{mg} \mathrm{kg}^{-1}$ and an exchangeable $\mathrm{K}$ content of $68.4 \mathrm{mg} \mathrm{kg}^{-1}$. Therefore, sugarcane grown in Aeric Endoaquepts soil was unsuitable with limitations of waterlogging based on Agricultural Economics Crop Zoning data that prepared by the Land Development Department (Ministry of Agriculture and Cooperatives, 2018). Waterlogged condition has an impact on agro-morphological traits leading to decrease of sugarcane productivity (Islam et al., 2011; Anitha et al., 2016; Khaiyam et al., 2018; ).

The soil from the second area (Yanyaow Sub-district, Sawankhalok District) was classified as Aquic Haplustalfs soil derived from alluvial fans. Data (Table 1) shows that the soil had a moderate permeability and vegetation with land application currently as sugarcane. Soil characteristics and properties indicated that topsoil and subsoil textures were silty loam to silty clay. Soil color was brownish brown and dark brown (Fig 1a.). Based on chemical properties, the topsoil (0-20 cm depth) had relatively high content of organic matter $(2.5 \%)$, while nitrogen $(0.05 \%)$ and exchangeable potassium content $\left(26.2 \mathrm{mg} \mathrm{kg}^{-1}\right)$ were very low. Available phosphorus content $\left(10.61 \mathrm{mg} \mathrm{kg}^{-1}\right)$ was at a moderate level. The Aquic Haplustalfs soil was more suitable for sugarcane planting because of silty loam to silty clay texture compared to Aeric Endoaquepts soil (Jongskul, 2016).
Moreover, Aquic Haplustalfs soil of Yanyaow Sub-district had higher soil organic matter content compared to soil of Koh Ta Liang Sub-district. Bokhtiar (2015) mentioned that 2.5 to $3.0 \%$ soil organic matter was necessary for sustainable sugarcane production.

\section{Physicochemical properties of NCS products}

Following the traditional evaporation process, phytochemical compounds of NCS products made from sugarcane cultivar LK-92-11 grown under the two different soil qualities, were evaluated. NCS products were made every week for three weeks during February 2016. Sugarcane was harvested from Koh Ta Liang Sub-district (SR1-3) and Yanyaow Sub-district (SK1-3). The obtained NCS products (Fig 2.) were processed to analyze physicochemical properties and phytochemical contents. Total soluble solids (Brix) and $\mathrm{pH}$ of raw cane juice from LK-92-11 cane cultivar grown in the two different areas were assessed as $21.8-22.0{ }^{\circ} \mathrm{B}$ and $\mathrm{pH} 4.6-5.0$, respectively. Juice analysis also indicated that the $\mathrm{pH}$ of raw cane juice form sugarcane planted in Aquic Haplustalfs ranged from 4.6 to 5.2 and in Aeric Endoaquepts was 5.0 (data not shown). Total soluble solid contents indicating the sweetness of NCS products obtained from two areas are slightly different since the major constituent of non-centrifugal brown sugar is sucrose $(80-87 \%)$ following monosaccharide including fructose and glucose (Simko and Polovkov, 2017; Asikin et al., 2017).

Physicochemical properties of NCS products (Table 2.) indicated that color value of sugarcane product from Aquic Haplustalfs soil $(40,200-36,566$ IU) was significantly $(p \leq 0.05)$ higher than sugarcane from Aeric Endoaquepts soil $(14,700-20,533$ IU). Color formation of NCS products is caused by four different mechanisms including: (1) melanoidin from Maillard reaction; (2) caramelization from thermal degradation of sugar; (3) degradation of reducing sugar; (4) oxidative reaction of phenolic compound (Carolyn \& Bucheli, 1994). Phenolic and flavonoid pigments therefore retained in final products play an important role on color of NCS products (Payet et al., 2005). With the same process condition, total phenolic and flavonoid contents of NCS products produced by cane from Aquic Haplustalfs (Yanyaow Sub-district) were higher than sugarcane from Aeric Endoaquepts soil (Koh Ta Liang Sub-district) (Table 3).

Wax content is an indicator of policosanol contents of NCS products from sugarcane. The wax content of NCS product from the Aquic Haplustalfs soil (2.61-3.00\%) showed higher than one from the Aeric Endoaquepts (1.59-2.04\%). The amount of sugarcane surface wax is cultivar dependent and affected by the maturity stage, extract juice process, nutrients in the soil and time of harvesting (Colombo et al., 2005). Total acidity of NCS products in sugarcane from the Aquic Haplustalfs soil $(0.89-1.10 \%)$ was also higher than products from the Aeric Endoaquepts (0.30-0.35\%). This was in agreement with $\mathrm{pH}$ of raw cane juice found in the study but it was contradict to the $\mathrm{pH}$ of soil in the two areas. The result might imply that the more acidic of raw juice and products is not contributed to the more acidic property of soil. Zambrosi (2014) found that soil $\mathrm{pH}$ affects phosphorus availability for plant uptake. Low soil pH (acidic condition) severely limits phosphorus availability to plants, which may cause deficiency symptoms and link to plant growth (Zambrosi et al, 2014). The result showed that the Aeric Endoaquepts soil ( $\mathrm{pH}$ of 5.1) is more acidic than Aquic Haplustalfs soil ( $\mathrm{pH}$ of 6.2 ) and the phosphorus content of Aeric Endoaquepts soil was lower than one of Aquic Haplustalfs soil (Table 1). 
Effect of soil properties in the two areas on policosanol and tricin components of NCS products

Policosanols comprise a group of long-chain aliphatic primary alcohols (C22-C30) as characteristic nutraceuticals in sugarcane. They exhibit health promotion by reducing platelet aggregation as well as serum low-density lipoprotein levels, and inhibiting cholesterol synthesis, leading to the risk reduction of atherosclerosis (Noa \& Mas, 2005; Singh et al., 2006). An overview of the beneficial health effects of $C-28$ has also been reported (Taylor et al., 2003). The flavonoid tricin is a nutraceutical not normally found in the most consumed plant food, which has been reported in rice, cereal, and sugarcane (Irmak et al., 2006). Tricin exhibits chemopreventive properties as growth inhibition of human malignant breast tumor cells and protection of murine gastrointestinal carcinogenesis (Cai et al., 2005; Verschoyle et al., 2006). Compositions of PC contents of all NCS products (Table 3.) showed oxtacosanol $(\mathrm{C} 28-\mathrm{OH})$ and triacosanol $(\mathrm{C} 30-\mathrm{OH})$ as the main components. PC contents of NCS products from the Aquic Haplustalfs soil $\left(8.80-9.38 \mathrm{mg} 100 \mathrm{~g}^{-1}\right)$ were higher than from the Aeric Endoaquepts soil $\left(7.80-8.17 \mathrm{mg} 100 \mathrm{~g}^{-1}\right)$. The two different soil types gave sugar products with significant differences $(p \leq 0.05)$ in PC contents. This result was in accordance with wax contents in Table 2. Tricin contents of NCS products from the Aeric Endoaquepts soil (113.39-124.83 $\mu \mathrm{g} 100 \mathrm{~g}^{-1}$ ) were higher than from the Aquic Haplustalfs soil (96.58-111.43 $\mu \mathrm{g} 100 \mathrm{~g}^{-1}$ ) (Table 3.). This phenomenon suggested that soil properties affected PC and tricin contents in NCS products.

Total phenolic contents (TPC), total flavonoid contents (TFC) and antioxidant properties of NCS

Other indicators of nutraceutical food product compounds include total phenolic contents (TPC), total flavonoid contents (TFC) and antioxidant activities. TPC (35.76-38.37 mg GAE $\left.100 \mathrm{~g}^{-1}\right)$ and TFC (27.35-31.46 mg RUE $\left.100 \mathrm{~g}^{-1}\right)$ of NCS products from the Aquic Haplustalfs soil were higher than from the Aeric Endoaquepts soil (17.69-23.28 mg GAE $100 \mathrm{~g}^{-1}$ and 12.28-17.01 mg RUE $100 \mathrm{~g}^{-1}$, respectively) (Table 3). TPC of NCS products found here were much lower than values reported by Payet et al. (2005) for commercial brown sugars

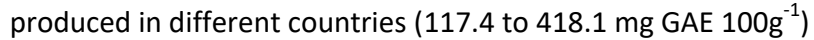
(Nayaka et al., 2009), for Jaggery, an Indian NCS, (383 mg GEA $100 \mathrm{~g}^{-1}$ ) and for Kokuto, a Japanese NCS (92.88 to $154.92 \mathrm{mg}$ GAE $100 \mathrm{~g}^{-1}$ ) (Takahashi et al., 2016). This might be due to differences in phenolic and flavonoid extraction methods such as duration, solvent, time and sugarcane varieties. Radical scavenging activities of the two different NCS products were determined by DPPH, FRAP and ORAC assay. The NCS products from the Aquic Haplustalfs soil showed high antioxidant activity (DPPH, FRAP and ORAC radical scavenging activity) compared with product from the Aeric Endoaquepts soil. Antioxidant activities concurred with results of TPC and TFC contents. Higher bioactivities as antioxidant activities were attributed to large amounts of bioactive compounds. The results suggested that NCS product from Aquic Haplustalfs soil contain high value of nutraceutucal contents and bioactivity as antioxidant activity compared with product from the Aeric Endoaquepts soil. In addition, the high value of phytochemicals and antioxidant activities might be from the higher soil organic matter content of Aquic Haplustalfs soil compared with the Aeric Endoaquepts soil.
Pearson's correlation between soil properties and phytochemical components of NCS from the two different soil types

Pearson's correlation was used to evaluate the relationship between soil properties and nutraceutical contents of the NCS products. Results are shown in Table 4. Except for tricin, PC contents and other nutraceutical indicators including TFC, TFC, and antioxidant activities by, DPPH, FRAP and ORAC assay showed negative correlation with soil electrical conductivity (EC) and exchangeable potassium content (K). This suggested that soil with higher EC and exchangeable $\mathrm{K}$ contents produced sugarcane and NCS products with lower nutraceutical and antioxidant activities. The relationship of soil component and nutraceutical contents is shown in Fig.3. The $\mathrm{EC}$ and exchangeable $\mathrm{K}$ values of the Aquic Haplustalfs soil were $0.02 \mathrm{ds} \mathrm{m}^{-1}$ and 26.2-17.1 $\mathrm{mg} \mathrm{kg}^{-1}$, respectively compared with the Aeric Endoaquepts soil at $0.03-0.05 \mathrm{ds} \mathrm{m}^{-1}$ and 68.4-16.3 $\mathrm{mg} \mathrm{kg}^{-1}$, respectively. The recent result was disagreement with the report of Dumas (2003) who reported that potassium deficiency might result in a decrease of lycopene level in tomato (Dumas et al., 2003).

On the contrary, the $\mathrm{pH}$ value, available phosphorus content $(\mathrm{P})$, and organic matter (OM) had a strong positive correlation with PC content and other nutraceutical indicators including TFC, TFC, and antioxidant activities by, DPPH, FRAP and ORAC assay, except for tricin contents. The $\mathrm{pH}$ value, available phosphorus content, and organic matter of the Aquic Haplustalfs soil were 6.2-6.1 (60 meter depth), 10.61-1.77 mg $\mathrm{kg}^{-1}$, and 2.1-2.5\%, respectively whereas those of the Aeric Endoaquepts soil were $5.1-5.7,3.9-2.6 \mathrm{mg} \mathrm{kg}^{-1}$, and $1.3-1.7 \%$, respectively. To date, little information in the literature has been given to link soil conditions to phytochemical, the secondary metabolites with potential health-promoting effect of crop. Oliveira (2003) concluded that amount of carotenoid in grapes (Vitis vinifera) were more affected by soil characteristics than irrigation. There was a $60 \%$ reduction of carotenoids in irrigated grapes grown on a lower-water-retention soil compared to non-irrigated grapes (Oliveira et al., 2003). Mozafar (1993) reported that carotenoid content in fruit and vegetables tended to increase with higher nitrogen value (Mozafar, 1993). The result that Aeric Endoaquepts soil was characterized as the limitations of waterlogging and lower nitrogen value might explain that NCS product from Aeric Endoaquepts soil contain low value of phytochemical contents and bioactivity as antioxidant activity compared with product from the Aquic Haplustalfs soil. Given the limitations of most published studies, the future researchs are required.

\section{Materials and Methods}

\section{Plant materials and Study area}

The experimental field was located in Sukhothai Province, Thailand. Two areas of the natural cane field environment were planted with the same sugarcane cultivar of LK-92-11 under similar crop management to assess differences in soil quality. The farmers were asked to apply the same crop management. Fertilizer of NPK (15-15-15) at a rate of $21 \mathrm{~kg} \mathrm{~N}$ $\mathrm{ha}^{-1}$, together with urea $(46-0-0)$ at a rate of $65 \mathrm{~kg} \mathrm{~N} \mathrm{ha}^{-1}$ were applied only one time. The first area was Koh Ta Liang Sub-district $\left(17^{\circ} 13^{\prime} 36.7^{\prime \prime} \mathrm{N}\right.$ and $\left.99^{\circ} 86^{\prime} 09.3^{\prime \prime E}\right)$, Srisomrong 
Table 1. Soil physicochemical properties of Aeric Endoaquepts and Aquic Haplustalfs.

\begin{tabular}{|c|c|c|c|c|c|}
\hline $\begin{array}{c}\text { Physicochemical } \\
\text { properties }\end{array}$ & $\begin{array}{l}\text { Depth } \\
(\mathrm{cm})\end{array}$ & $\begin{array}{c}\text { Organic } \\
\text { matter (\%) }\end{array}$ & $\begin{array}{l}\text { Nitrogen } \\
(\%)\end{array}$ & $\begin{array}{l}\text { Available phosphorus } \\
\qquad\left(\mathrm{mg} \mathrm{kg}^{-1}\right)\end{array}$ & $\begin{array}{c}\text { Exchangeable } \\
\text { potassium }\left(\mathrm{mg} \mathrm{kg}^{-1}\right)\end{array}$ \\
\hline \multicolumn{6}{|c|}{ Aeric Endoaquepts (Kautaliang Sub-district, Srisomrong District (SR)) $(x=0591578, y=1894546)$} \\
\hline & $0-20$ & $\begin{array}{c}1.7 \\
\text { (medium) }\end{array}$ & $\begin{array}{c}0.05 \\
\text { (very low) }\end{array}$ & $\begin{array}{r}3.97 \\
\text { (low) } \\
\end{array}$ & $\begin{array}{c}68.4 \\
\text { (medium) }\end{array}$ \\
\hline & $20-40$ & $\begin{array}{c}1.3 \\
\text { (rather low) }\end{array}$ & $\begin{array}{c}0.03 \\
\text { (very low) } \\
\end{array}$ & $\begin{array}{c}2.64 \\
\text { (very low) } \\
\end{array}$ & $\begin{array}{c}16.3 \\
\text { (very low) } \\
\end{array}$ \\
\hline & & $\begin{array}{c}1.1 \\
\text { (rather low) } \\
\end{array}$ & $\begin{array}{c}0.05 \\
\text { (very low) } \\
\end{array}$ & $\begin{array}{c}3.84 \\
\text { (very low) } \\
\end{array}$ & $\begin{array}{c}9.7 \\
\text { (very low) } \\
\end{array}$ \\
\hline & $60-80$ & $\begin{array}{c}1.0 \\
\text { (rather low) }\end{array}$ & $\begin{array}{c}0.05 \\
\text { (very low) }\end{array}$ & $\begin{array}{c}4.54 \\
(\text { low }) \\
\end{array}$ & $\begin{array}{c}10.0 \\
\text { (very low) }\end{array}$ \\
\hline & $80-100$ & $\begin{array}{c}1.2 \\
\text { (rather low) } \\
\end{array}$ & $\begin{array}{c}0.03 \\
\text { (very low) } \\
\end{array}$ & $\begin{array}{c}2.83 \\
\text { (low) }\end{array}$ & $\begin{array}{c}11.1 \\
\text { (very low) }\end{array}$ \\
\hline & $100-120$ & $\begin{array}{c}1.0 \\
\text { (rather low) }\end{array}$ & $\begin{array}{c}0.03 \\
\text { (very low) } \\
\end{array}$ & $\begin{array}{c}2.61 \\
\text { (very low) } \\
\end{array}$ & $\begin{array}{c}11.1 \\
\text { (very low) } \\
\end{array}$ \\
\hline & $120-140$ & $\begin{array}{c}0.8 \\
\text { (low) }\end{array}$ & $\begin{array}{c}0.03 \\
\text { (very low) }\end{array}$ & $\begin{array}{c}2.83 \\
\text { (very low) }\end{array}$ & $\begin{array}{c}9.6 \\
\text { (very low) }\end{array}$ \\
\hline \multicolumn{6}{|c|}{ Aquic Haplustalfs (Yanyaow Sub-district, Sawankhalok District (SK)) $(x=0587717, y=1910831)$} \\
\hline & $0-20$ & $\begin{array}{c}2.5 \\
\text { (relatively high) }\end{array}$ & $\begin{array}{c}0.05 \\
\text { (very low) }\end{array}$ & 10.61 (medium) & $\begin{array}{c}26.2 \\
\text { (very low) } \\
\end{array}$ \\
\hline & $20-40$ & $\begin{array}{c}2.1 \\
\text { (medium) }\end{array}$ & $\begin{array}{c}0.05 \\
\text { (very low) } \\
\end{array}$ & 13.62 (medium) & $\begin{array}{c}17.1 \\
\text { (very low) }\end{array}$ \\
\hline & $40-60$ & $\begin{array}{c}1.1 \\
\text { (rather low) }\end{array}$ & $\begin{array}{c}0.03 \\
\text { (very low) }\end{array}$ & $\begin{array}{c}1.77 \\
\text { (very low) }\end{array}$ & $\begin{array}{c}1.1 \\
\text { (very low) }\end{array}$ \\
\hline & $60-80$ & $\begin{array}{c}0.7 \\
\text { (low) }\end{array}$ & $\begin{array}{c}0.03 \\
\text { (very low) }\end{array}$ & $\begin{array}{c}4.26 \\
\text { (low) } \\
\end{array}$ & $\begin{array}{c}0.7 \\
\text { (very low) } \\
\end{array}$ \\
\hline & $80-100$ & $\begin{array}{c}1.0 \\
\text { (rather low }\end{array}$ & $\begin{array}{c}0.03 \\
\text { (very low) } \\
\end{array}$ & $\begin{array}{c}1.38 \\
\text { (very low) }\end{array}$ & $\begin{array}{c}1.0 \\
\text { (very low) }\end{array}$ \\
\hline$x^{2}$ & $100-120$ & $\begin{array}{c}0.9 \\
\text { (low) }\end{array}$ & $\begin{array}{c}0.03 \\
\text { (very low) }\end{array}$ & $\begin{array}{c}2.41 \\
\text { (very low) }\end{array}$ & $\begin{array}{c}0.9 \\
\text { (very low) }\end{array}$ \\
\hline
\end{tabular}

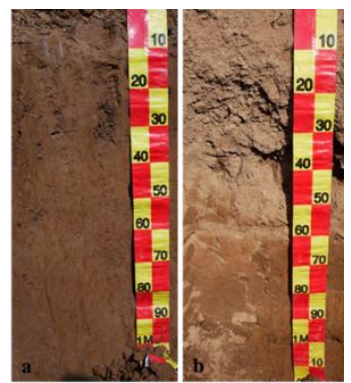

Fig 1. Soil types from a: Yanyaow Sub-district, Sawankhalok District as Si Satchanalai (Aquic Haplustalfs) $(x=0587717, y=1910831$ ), and b: Kautaliang Sub-district, Srisomrong District as Chai Nat (Aeric Endoaquepts) ( $x=0591578, y=1894546)$.

Table 2. Physicochemical properties of non-centrifugal sugarcane products from the two different soil qualities.

\begin{tabular}{clllll}
\hline NCS product & ICUMSA color (IU) & $\begin{array}{l}\text { Moisture content } \\
(\%)\end{array}$ & Water activity ${ }^{\text {ns }}$ & $\begin{array}{l}\text { Total acidity } \\
(\%)^{\text {s }}\end{array}$ & Wax content (\%) \\
\hline SK1 & $40200 \pm 0.07 \mathrm{~d}$ & $8.99 \pm 0.09 \mathrm{~b}$ & $0.52 \pm 0.20$ & $0.89 \pm 0.01$ & $3.00 \pm 1.19 \mathrm{~d}$ \\
SK2 & $36566 \pm 0.05 \mathrm{c}$ & $9.59 \pm 0.03 \mathrm{a}$ & $0.56 \pm 0.10$ & $1.07 \pm 0.00$ & $3.87 \pm 2.37 \mathrm{e}$ \\
SK3 & $39500 \pm 0.01 \mathrm{~d}$ & $9.06 \pm 0.15 \mathrm{ab}$ & $0.57 \pm 0.10$ & $1.10 \pm 0.01$ & $2.61 \pm 0.82 \mathrm{c}$ \\
SR1 & $14700 \pm 0.01 \mathrm{a}$ & $7.08 \pm 0.30 \mathrm{c}$ & $0.52 \pm 0.01$ & $0.37 \pm 0.01$ & $1.59 \pm 0.26 \mathrm{a}$ \\
SR2 & $15900 \pm 0.02 \mathrm{a}$ & $6.00 \pm 0.38 \mathrm{~d}$ & $0.48 \pm 0.01$ & $0.30 \pm 0.01$ & $2.04 \pm 0.12 \mathrm{~b}$ \\
SR3 & $20533 \pm 0.02 \mathrm{~b}$ & $8.68 \pm 0.11 \mathrm{~b}$ & $0.52 \pm 0.02$ & $0.35 \pm 0.01$ & $1.64 \pm 0.08 \mathrm{a}$ \\
\hline
\end{tabular}

Values are the mean $+S D, n=3$. Means in the same column with same superscript letter are not significant at $p<0.05$.

SK = sugar products from cane planting in Si Satchanalai (Aquic Haplustalfs); SR = sugar products from cane planting in Chai Nat (Aeric Endoaquepts); NS = non-significant difference; NCS products were produced and corrected for three consecutive analyses.

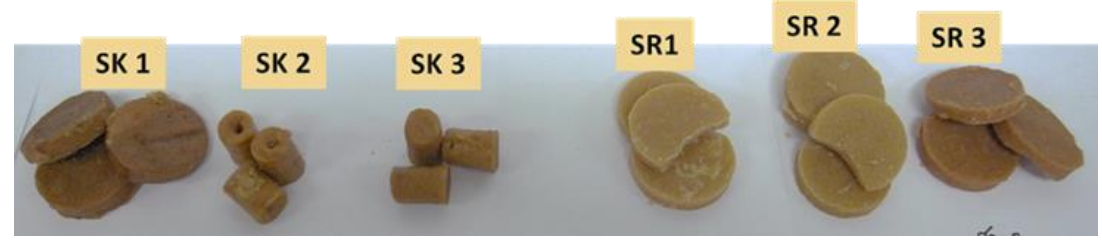

Fig 2. Non-centrifugal sugar products produced by sugarcane cultivar of LK-92-11 harvested from different soil types (SK1-SK3 from Si Satchanalai (Aquic Haplustalfs) and SR1-SR3 from Chai Nat (Aeric Endoaquepts). 
Table 3. Nutraceutical contents and antioxidant activity of NCS products from the two different soil qualities.

\begin{tabular}{|c|c|c|c|c|c|c|}
\hline \multirow{2}{*}{ Nutraceutical } & \multicolumn{5}{|c|}{ NCS products } & \multirow[b]{2}{*}{ SR3 } \\
\hline & SK1 & SK2 & SK3 & SR1 & SR2 & \\
\hline \multicolumn{7}{|l|}{ Policosanol } \\
\hline Docosanol (C-22) & $1.34 \pm 0.12$ & $1.35 \pm 0.02$ & $1.47 \pm 0.02$ & $1.42 \pm 0.08$ & $1.08 \pm 0.19$ & $0.18 \pm 0.06$ \\
\hline Tetracosanol (C-24) & $0.46 \pm 0.01$ & $0.51 \pm 0.06$ & $0.52 \pm 0.02$ & $0.66 \pm 0.30$ & $0.52 \pm 0.01$ & $0.14 \pm 0.02$ \\
\hline Hexacosanol (C-26) & $0.58 \pm 0.09$ & $0.61 \pm 0.05$ & $0.58 \pm 0.03$ & $0.62 \pm 0.13$ & $0.58 \pm 0.02$ & $0.29 \pm 0.04$ \\
\hline Octacosanol (C-28) & $4.20 \pm 0.25$ & $4.14 \pm 0.08$ & $3.90 \pm 0.06$ & 3. $04 \pm 0.10$ & $3.00 \pm 0.22$ & $2.73 \pm 0.26$ \\
\hline Triacontanol (C-30) & $1.97 \pm 0.08$ & $2.07 \pm 0.14$ & $1.54 \pm 0.23$ & $1.86 \pm 0.52$ & $1.74 \pm 0.04$ & $1.29 \pm 0.34$ \\
\hline Total policosanol (mg $\left.100 \mathrm{~g}^{-1} \mathrm{wb}\right)$ & $8.55 \pm 0.13 a$ & $8.68 \pm 0.19 a$ & $8.00 \pm 0.21 a$ & $7.59 \pm 0.87 b$ & $6.88 \pm 0.45 c$ & $4.63 \pm 0.54 d$ \\
\hline Total policosanol $\left(\mathrm{mg} / 100 \mathrm{~g}^{-1} \mathrm{db}\right)$ & $9.38 \pm 0.14 b$ & $9.60 \pm 0.21 a$ & $8.80 \pm 0.23 c$ & $8.17 \pm 0.94 d$ & $7.32 \pm 0.48 f$ & $7.80 \pm 0.26 \mathrm{e}$ \\
\hline Tricin contents $\left(\mu \mathrm{g} 100 \mathrm{~g}^{-1}\right)$ & $111.43 \pm 11.36 \mathrm{ab}$ & $106.48 \pm 3.29 a b$ & $96.58 \pm 3.90 \mathrm{~b}$ & $128.04 \pm 2.44 a b$ & $113.39 \pm 7.56 \mathrm{a}$ & $128.43 \pm 4.89 a$ \\
\hline TPC (mg GAE $100 \mathrm{~g}^{-1}$ ) & $35.76 \pm 0.06 \mathrm{c}$ & $38.95 \pm 0.05 a$ & $38.37 \pm 0.14 \mathrm{~b}$ & $17.69 \pm 0.17 f$ & $19.14 \pm 0.10 \mathrm{e}$ & $23.83 \pm 0.16 \mathrm{~d}$ \\
\hline TFC (mg RUE100g $\left.{ }^{-1}\right)$ & $27.35 \pm 0.84 b$ & $31.46 \pm 0.07 a$ & $31.24 \pm 0.37 a$ & $12.28 \pm 0.56 \mathrm{e}$ & $15.36 \pm 0.42 d$ & $17.01 \pm 0.24 c$ \\
\hline$\%$ DPPH radical Inhibition & $96.72 \pm 0.01 a$ & $95.91 \pm 0.07 a$ & $95.26 \pm 0.12 a$ & $66.63 \pm 1.25 b$ & $73.67 \pm 0.07 c$ & $87.97 \pm 0.76 \mathrm{~d}$ \\
\hline $\operatorname{FRAP}\left(\mathrm{mg} \mathrm{FeSO}_{4} \mathrm{~g}^{-1}\right)$ & $1,391.2 \pm 9.2 b$ & $1,455.7 \pm 7.7 a$ & $1,468.0 \pm 33.6 a$ & $791.2 \pm 7.5 \mathrm{e}$ & $883.6 \pm 11.4 \mathrm{~d}$ & $974.0 \pm 9.2 c$ \\
\hline ORAC (mgTE g $\left.{ }^{-1}\right)$ & $31.07 \pm 2.47 \mathrm{ab}$ & $39.43 \pm 5.63 a$ & $38.16 \pm 8.22 \mathrm{a}$ & $13.95 \pm 2.68 \mathrm{~b}$ & $13.98 \pm 1.87 \mathrm{~b}$ & $21.97 \pm 1.26 \mathrm{ab}$ \\
\hline
\end{tabular}

Values are the mean $\pm S D, n=3$. Means in the same horizontal with same superscript letter are not significant at $p<0.05$.

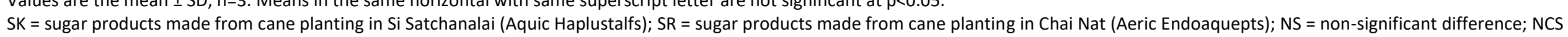
products were produced and corrected for three consecutive analyses.

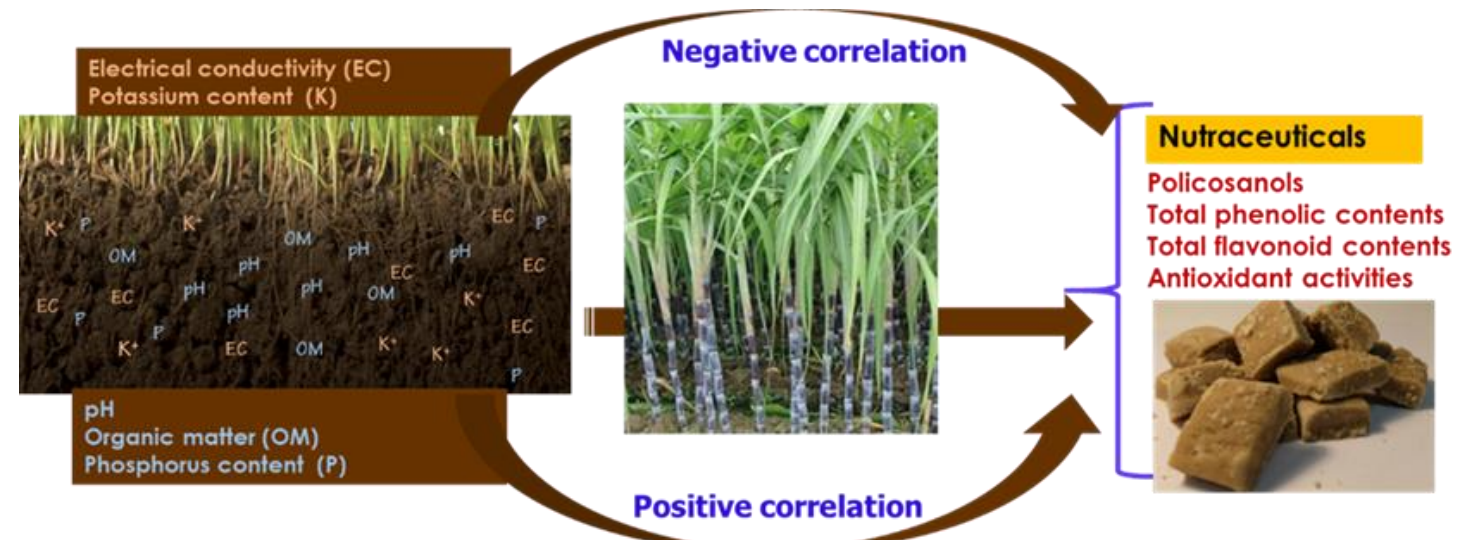

Fig 3. The relationship of soil properties and nutraceutical of non-centrifugal sugar products from pearson's correlation. 
Table 4. Pearson's correlation between soil properties and chemical properties of NCS products from the two different soil types.

\begin{tabular}{|c|c|c|c|c|c|c|}
\hline Properties & $\% O M$ & $\mathrm{pH}$ & $\begin{array}{l}\mathrm{EC} \\
\left(\mathrm{dSm}{ }^{-1}\right)\end{array}$ & $\% \mathrm{~N}$ & $\begin{array}{l}\text { Available } \\
\text { phosphorus } \\
\left(\mathrm{mg} \mathrm{kg}^{-1}\right)\end{array}$ & $\begin{array}{l}\text { Exchangeable } \\
\text { potassium } \\
\left(\mathrm{mg} \mathrm{kg}^{-1}\right)\end{array}$ \\
\hline$P C\left({\left.\mathrm{mg} 100 \mathrm{~g}^{-1}\right)}\right.$ & 0.07 & $0.81^{*}$ & -0.70 & -0.12 & 0.33 & -0.51 \\
\hline Tricin (mg $100 \mathrm{~g}^{-1}$ ) & -0.08 & -0.72 & 0.70 & 0.35 & -0.23 & 0.51 \\
\hline Flavonoid (mg $1 \mathrm{~g}^{-1}$ ) & 0.56 & $0.85^{*}$ & $-0.85^{*}$ & 0.25 & 0.64 & -0.23 \\
\hline $\begin{array}{l}\text { Phenolic contents } \\
\left(\mathrm{mg} \mathrm{g}^{-1}\right)\end{array}$ & 0.51 & $0.86^{*}$ & $-0.85^{*}$ & 0.23 & -0.61 & -0.27 \\
\hline \% DPPH & 0.49 & $0.89 *$ & $-0.81^{*}$ & 0.22 & 0.61 & -0.32 \\
\hline FRAP $\left(\mathrm{mg} \mathrm{FeSO}_{4} \mathrm{~g}^{-1}\right)$ & 0.52 & $0.87^{*}$ & $-0.84 *$ & 0.23 & 0.63 & -0.27 \\
\hline ORAC (mg TE $\left.100 \mathrm{~g}^{-1}\right)$ & 0.30 & $0.89 *$ & -0.70 & -0.20 & 0.59 & -0.50 \\
\hline
\end{tabular}

** Correlation is significant at the 0.01 level (2-tailed). ${ }^{*}$ Correlation is significant at the 0.05 level (2-tailed). PC: Policosanol contents, FRAP: Ferric reducing antioxidant power, ORAC: Oxygen radical absorbance capacity. OM: Organic matter, EC: Electrical conductivity

District (SR), and the second site was Yanyaow Sub-district $\left(17^{\circ} 28^{\prime} 10.2^{\prime \prime} \mathrm{N}\right.$ and $\left.99^{\circ} 82^{\prime} 52.8^{\prime \prime E}\right)$, Sawankhalok District (SK). Following the Köppen classification, climate at the site was assessed to be Aw as tropical, savannah, wet with three seasons; (I) rainy, (II) dry and cool, and (III) dry and hot. Mean annual temperature was $28{ }^{\circ} \mathrm{C}$ and average annual precipitation 1,208 $\mathrm{mm}$. In the rainy season (May to October), most rain fell between July and September (Meteorological Department, Ministry of Information and Communication Technology, 2017). Sugarcane samples were collected from each sampling area at the same time and sample place with soil sample for making non-centrifugal cane brown sugar and analysis of phytochemical contents.

Soil at Koh Ta Liang Sub-district was classified according to the Soil Survey Manual compiled by Soil Science Division Staff (2014) as Aeric Endoaquepts soil (Chai Nat soil series; (Cn) the National Soil Classification System of Thailand). This soil is formed from alluvium and occurs on river levees and alluvium fans. The relief varies from nearly level to gently undulating with slopes ranging from 0 to $2 \%$. For Yanyaow Sub-district, soil was classified as Aquic Haplustalfs soil (Soil Survey Division Staff, 2014) (Si Satchanalai series (Sir); the National Soil Classification System of Thailand).

\section{Standards and reagents}

2, 2-diphenyl-1-picrylhydrazyl (DPPH), 2, 2-azino-bis (3-ethylbenzthiazoline-6-sulfonic acid) (ABTS), and Folin-Ciocalteu's reagent were purchased from Sigma-Aldrich, Germany. 6-Hydroxy-2, 5, 7, 8-tetramethylchromane2-carboxylic acid (Trolox), and rutin hydrate were obtained from Sigma-Aldrich (China). Gallic acid was obtained from Merck KGaA (Germany). Standard policosanols (C20-C30) were purchased from Sigma-Aldrich (Switzerland and Germany). Standard tricin was obtained from Dalton Pharma Services (Canada).

\section{Soil sampling}

Soil samples were collected in November 2016 as disturbed soil from seven plots at each site. Each plot was divided into 3 parts and 5 samples were randomly collected from each part between row and inter-row and then combined into one sample. Samples were collected at two depths of 0-20 and $20-40 \mathrm{~cm}$. Fifteen soil sub-samples were collected from each sampling area ( $0.6 \mathrm{ha}) .1 \mathrm{~kg}$ of the composite soil sample was taken for soil chemical analysis.

\section{Soil laboratory analysis}

\section{Electrical conductivity (EC)}

Electrical conductivity of saturated soil-paste extracts was measured according to Rhoades et al. (1996). A $1 \mathrm{~g}$ soil sample was dissolved in distilled water $(5 \mathrm{~mL})$ with continuous stirring for $30 \mathrm{~min}$. After settling, measurement using an electrical

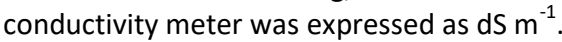

\section{Determination of organic matter (OM) in soil}

Determination of soil organic matter was based on the method used by Walkley and Black (1996). A $0.5 \mathrm{~g}$ sample was mixed with $1 \mathrm{~N}$ potassium dichromate $\left(\mathrm{K}_{2} \mathrm{Cr}_{2} \mathrm{O}_{7}\right)$ solution $(5 \mathrm{ml})$ and sulfuric acid $\left(\mathrm{H}_{2} \mathrm{SO}_{4}\right)(10 \mathrm{~mL})$. The mixture was then left to stand for $30 \mathrm{~min}$ before adding distilled water $(15 \mathrm{~mL})$ and titrating with $5 \mathrm{~N}$ ferrous sulfate $\left(\mathrm{FeSO}_{4}\right)$ with $\mathrm{O}$-phenolphthalein as the $\mathrm{pH}$ indicator. The value of organic matter was calculated from the equation below:

$\%$ Organic carbon $=\left(\mathrm{N} \mathrm{K}_{2} \underline{\mathrm{Cr}}_{2} \mathrm{O}_{7} \times \mathrm{V} \mathrm{K}_{2} \underline{\mathrm{Cr}}_{2} \mathrm{O}_{7}-\mathrm{N} \mathrm{FeSO}_{4} \times \underline{\mathrm{V} \mathrm{FeSO}}_{4}\right)$ $\times 0.003 \times 100 \times 1.33$ Weight of sample

Where, $\mathrm{N}=$ concentration of chemical, $\mathrm{V}=$ volume

$\%$ organic matter $=\%$ organic carbon $\times 1.724$.

\section{Determination of total nitrogen ( $N$ )}

Determination of soil nitrogen was based on the Kjeldahl method (Bremner, 1996) and used to determine total nitrogen (N).

\section{Determination of available phosphorus}

Available phosphorus was determined according to the Bray II method (Bray and Kurtz, 1996). Soil sample of $2 \mathrm{~g}$ was mixed with the extractor Bray II $(20 \mathrm{~mL})$ and shaken for $40 \mathrm{sec}$ before filtration (filter paper No. 42) andmeasured by a spectrophotometer (Milton Roy, Spectronic Genesys 5) at 882 $\mathrm{nm}$. Available phosphorus was calculated from the obtained linear calibration curve of phosphorus and expressed as $\mathrm{mg} \mathrm{L}^{-1}$.

\section{Determination of exchangeable potassium}

Exchangeable potassium (K) was determined according to Pratt (2017). A soil sample of $5 \mathrm{~g}$ was shaken with $50 \mathrm{~mL}$ of ammonium acetate $\left(\mathrm{NH}_{4} \mathrm{OAc}\right)(1 \mathrm{~N})$. The mixture was then filtered (filter paper No. 42) and atomic absorption spectrophotometry was determined at $766 \mathrm{~nm}$. Exchangeable 
potassium was calculated from the linear calibration curve of potassium and expressed as $\mathrm{mg} \mathrm{L}^{-1}$.

\section{Preparation of non-centrifugal sugar product (NCS)}

Non-centrifugal sugar product (NCS) was produced from the LK-92-11 sugarcane cultivar in both areas as Yanyaow Sub-district (Si Satchanalai soil series) and Koh Ta Liang Sub-district (Chai Nat soil series) in Sukhothai Province, Thailand. After manually harvesting mature sugarcane (February 2016), whole stalks were immediately pressed to obtain raw cane juice. Following the traditional process, the raw cane juice was evaporated in an open pan $(60 \mathrm{~L})$ for 1.30 $\mathrm{hr}$ to produce NCS. This process was repeated every week for 3 weeks in February 2016. The obtained NCS products (Fig 2.) were stored at $-20{ }^{\circ} \mathrm{C}$ for further physicochemical and phytochemical analyses.

\section{Analyses of the physicochemical and phytochemical properties of NCS products}

\section{Moisture content and water activity analyses}

Moisture content was evaluated based on weight loss of a $2 \mathrm{~g}$ sample during oven drying at $105{ }^{\circ} \mathrm{C}$ for $3 \mathrm{hr}$, while water activity $\left(a_{w}\right)$ was measured using an IC-5000 AW-LAB Water Activity Analyzer (Novasina AG, Lachen, Switzerland).

\section{Color value analysis}

Color was determined according to the International Commission for Uniform Methods of Sugar Analysis (ICUMSA, 2003). Color value was calculated following ICUMSA and expressed as a color unit (Asikin et al., 2014). The sample (1 g) dissolved in distilled water $(100 \mathrm{~mL})$ was adjusted to $\mathrm{pH} 7.0$ with $0.1 \mathrm{~N}$ sodium hydroxide $(\mathrm{NaOH})$ solution. The mixture was then filtered (filter paper No. 42) and absorbance was measured at $420 \mathrm{~nm}$ by a spectrophotometer (Thermo Spectronic, USA). Color value was calculated using the equation:

ICUMSA color unit or IU $=($ absorbance $\times 1,000) /(b \times C)$

Where $\quad b$ is the cell path length used $(\mathrm{cm})$

$\mathrm{C}$ is the concentration of sugar solution ( $\mathrm{g}$

$\left.\mathrm{mL}^{-1}\right)$.

\section{Phenolic compounds and antioxidant activities determination}

Sugar samples $(20 \mathrm{~g})$ were extracted with $70 \mathrm{~mL}$ of $\mathrm{MeOH}$ solution $(1: 1 \mathrm{v} / \mathrm{v})$ with stirring for $60 \mathrm{~min}$ followed by filtration (filter paper No. 4). The solvent was removed using a rotary evaporator and the extract was adjusted with $\mathrm{MeOH}$ solution to a final volume of $50 \mathrm{~mL}$ (Weerawatanakorn et al., 2016). The extract was used to analyze total phenolic contents, total flavonoid contents (TFC), DPPH radical scavenging activity, and oxygen radical absorbance capacity (ORAC).

\section{Total phenolic contents (TPC)}

TPC of sugar extract was determined based on the Folin-Ciocalteu method of Weerawatanakorn et al. (2016), calculated from a linear calibration curve of gallic acid and expressed as mg GAE $100 \mathrm{~g}^{-1}$.

\section{Total flavonoid contents (TFC)}

TFC was performed following the method of Weerawatanakorn et al. (2016). Results were expressed as mg rutin equivalent $100 \mathrm{~g}^{-1}$.

\section{DPPH radical scavenging activity}

The ability of antioxidants in the sugar sample to inhibit DPPH radicals was determined following Weerawatanakorn et al. (2016). The antioxidant activity was calculated as a percentage of DPPH radical inhibition.

\section{Ferric reducing antioxidant power assay (FRAP)}

FRAP is based on the reduction of FellI ${ }^{+}$to $\mathrm{Fell}^{+}$due to the action of antioxidants present in the sample. FRAP was determined according to the method described by Manohar et al. (2017) with activity expressed as $\mathrm{mg} \mathrm{FeSO}_{4} \mathrm{~g}^{-1}$.

\section{Oxygen radical absorbance capacity (ORAC)}

ORAC was determined following the method described by Asikin et al. (2014), with slight modifications. Fluorescence intensity was kinetically recorded every minute for $60 \mathrm{~min}$ with fluorescent filters set at wavelengths of $485 \mathrm{~nm}$ excitation and $530 \mathrm{~nm}$ emission. Area under the curve (AUC) was calculated for relative fluorescence value. The ORAC values of the samples were compared with Trolox using a linear calibration curve and expressed as micromoles of Trolox equivalents (TE) per $g$ of sugar samples.

\section{Policosanol analysis}

Policosanol (PC) extraction was modified from the method of Weerawatanakorn et al. (2017) and Meerod et al. (2018). GC-FID was used to quantify policosanol contents. For qualification of PC compounds, PC standards or samples were prepared in chloroform $(0.5 \mathrm{~mL})$ and derivatized with MSTFA $(2: 1 \mathrm{v} / \mathrm{v})(250 \mu \mathrm{L})$ at $50^{\circ} \mathrm{C}$ for $15 \mathrm{~min}$ followed by addition of chloroform to obtain a $1 \mathrm{~mL}$ for mass spectrum identification.

GC-FID analysis was performed by a Shimadzu GC-2010 equipped with a fused capillary column (DB 5, $0.25 \mathrm{~mm}$ i.d. $\times$ $30 \mathrm{~m}$; J\&W Scientific, Folsom, CA, USA) and a flame ionization detector set at $350^{\circ} \mathrm{C}$. Helium was used as a carrier gas and sample solution $(1 \mu \mathrm{L})$ were injected with a split ratio of 1:10. Oven temperature was initially set to $150^{\circ} \mathrm{C}$, increased to 320 ${ }^{\circ} \mathrm{C}$ at the rate of $4^{\circ} \mathrm{C} \mathrm{min}^{-1}$, and then kept at $320^{\circ} \mathrm{C}$ for $15 \mathrm{~min}$. The PC content of sample was obtained by peak area calibrated by injecting mixture standards of PC at different concentrations.

\section{Tricin content analysis}

Tricin extraction was modified from the method of Colombo et al. (2005) and Meerod et al. (2018). Purified tricin (40 $\mu \mathrm{L})$ of NCS products was quantified by the liquid chromatography-mass spectrometry (LC-MS). An Agilent Technologies 1100 (Germany) with C-18 Column LiChroCART RP-18e (150 x $4.6 \mathrm{~mm}, 5 \mu \mathrm{m})$ (Purospher STAR Merck, USA) was used. Mobile phase was a linear gradient of acetonitrile (solvent $\mathrm{A}$ ) and $7 \% \mathrm{MeOH}(0.1 \%$ formic acid) (solvent $\mathrm{B}$ ) at a flow rate of $1.0 \mathrm{~mL} \mathrm{~min}^{-1}$. The gradient elution program was set at a constant ratio between solvent $A$ and $B$ (30:70). Temperature of the oven was set at $40{ }^{\circ} \mathrm{C}$. For mass detection, Nebulizer gas $\left(\mathrm{N}_{2}\right)$ pressure was set at 60 psi with dry gas flow 
at $13 \mathrm{~L} \mathrm{~min}^{-1}$ and dry temperature of $320^{\circ} \mathrm{C}$.

\section{Statistical analyses}

The experiments were conducted in triplicate and the results were expressed as mean \pm S.D. Research data were analyzed by Completely Randomized Design (CRD) and statistically significant differences were compared using Duncan's new multiple range test at a probability of $p<0.05$.

\section{Conclusions}

Non-centrifugal sugar products from sugarcane are sweeteners containing nutrients and phytochemical compounds which are beneficial to human health. Sugarcane planted in two different types of soil series provided variation of nutraceutical compounds in final NCS products obtained by traditional processes. NCS products from sugarcane planted in soil classified as Aquic Haplustalfs soil (Si Satchanalai) contained high amounts of nutraceuticals compared with NCS products from sugarcane planted in soil of Aeric Endoaquepts soil(the Chai Nat series). Higher nutraceutical contents of NCS products were found in Aquic Haplustalfs soil, with lower EC and exchangeable $\mathrm{K}$ values of $0.02 \mathrm{ds} \mathrm{m}^{-1}$ and 26.2-17.1 mg $\mathrm{kg}^{-1}$, respectively, while lower values were recorded in Aeric Endoaquepts soil with higher EC and exchangeable $\mathrm{K}$ values of $0.03-0.05 \mathrm{ds} \mathrm{m}^{-1}$ and $68.4-16.3 \mathrm{mg} \mathrm{kg}^{-1}$, respectively. The high phytochemical and antioxidant activity of NCS products is associated with the high organic matter of soil. This result is of benefit to sugarcane breeding research and can be used to improve sugarcane cultivars to meet increased quality demands in terms of nutraceutical components as well as in similar research involving the development of food products from sugarcane.

\section{Acknowledgements}

This research was financially supported by the National Research Council of Thailand, Research Project Numbers R2560B031 and RDG5950040

\section{References}

Anitha R, Mary PCNM, Purushothaman RS (2016) Biometric and physiological characteristics of sugarcane ratoon under waterlogging condition. Plant Arch. 16(1): 105-109.

Apichart Jongskul. 2016. Final report of National Agro-economic Zoning for Major Crops in Thailand (NAEZ) Project (TCP/THA/3403). Report prepared by National Agricultural Economist Consultant, 1 March 2016.

Asikin Y, Kamiya A, Mizu M, Takara K, Tamaki H (2014) Changes in the physicochemical characteristics, including flavor components and Maillard reaction products, of non-centrifugal cane brown sugar during storage. Food Chem. 149(15):170-177.

Asikin Y, Chinen T, Takara K, Wada K (2008) Determination of long-chain alcohol and aldehyde contents in the non-centrifuged cane sugar Kokuto. J Food Sci Technol. 14(6):583-588.

Asikin Y,Takahara W, Takahashi M, Hirose N, Ito S, \& Wada K. Compositional and electronic discrimination analyses of taste and aroma profiles of non-centrifugal cane brown sugars. Food Anal. Methods (2017) 10:1844-1856
Bokhtiar, SM, Roksana, S, Moslehuddin AZM (2015) Soil fertility and productivity of sugarcane influenced by enriched pressmud compost with chemical fertilizers. SAARC J. Agri. 13(2): 183-197.

Bremner JM (1996) Nitrogen-total, In: Methods of soil analysis. Part 3: Chemical methods. Bartels JM, Bigham JM (eds). The Soil Science Society of America and the American Society of Agronomy, Wisconsin-Madison, U.S.A. pp. 10851121.

Bray R, Kurtz LT (1945) Determination of total, organic, and available forms of phosphorus in soils. Soil Sci. 59(1):39-46.

Carolyn S, Bucheli CS, Robinson SP (1994) Contribution of Enzymic Browning to Color in Sugarcane Juice. J. Agric. Food Chem. 42(2): 257-261

Colombo R, Yariwake JH, Queiroz EF, Ndjoko K, Hostettmann K (2005) On-line identification of sugarcane (Saccharum officinarum L.) methoxy flavones by liquid chromatographyUV detection using post-column derivatization and liquid chromatography-mass spectrometry. Chromatography. 1082(1):51-59.

Cai H, Steward WP, Gescher AJ (2005) Determination of the putative cancer chemopreventive flavone tricin in plasma and tissue of mice by HPLC with UV-visible detection. Biomed Chromatogr. 19(7):518-522.

Cherubin MR, Karlen DL, Cerri CEP, Franco ALC, Tormena CA, Davies CA, Cerri CC (2016) Soil quality indexing strategies for evaluating sugarcane expansion in Brazil. Plos One. 11:1-6.

Duarte-Almeida JM, Negri G, Salatino A, de Carvalho JE, Lajolo FM (2007) Antiproliferative and antioxidant activities of a tricin acylated glycoside from sugarcane (Saccharum officinarum) juice. Phytochemistry. 68(8):1165-1171.

Dumas YM, Dadomo G, Lucca D, Grolier P (2003) Effects of environmental factors and agricultural techniques on antioxidant content of tomatoes. J. Sci. Food Agr. 83:369382.

Feng S, Luo Z, Zhang Y, Zhong Z, Lu B (2014) Phytochemical contents and antioxidant capacities of different parts of two sugarcane (Saccharum officinarum L.) cultivars. Food Chem. 151(15):452-458.

García JM, Narváez PC, Heredia FJ, Orjuela A, Osorio C (2017) Physicochemical and sensory (aroma and colour) characterisation of a non-centrifugal cane sugar ("panela") beverage. Food Chem. 228(1):7-13.

Irmak S, Dunford NT, Milligan J (2006) Policosanol contents of beeswax, sugar cane and wheat extracts. J Food chem. 95(2):312-318.

Iqbal M, Qamar MA, Bokhari TH, Abbas M, Hussain F, Masood N, Keshavarzi A, Qureshi N, Nazira A (2017) Total phenolic, chromium contents and antioxidant activity of raw and processed sugars. Inform Process Agric. 4:83-89.

Islam MS, Miah MAS, Begum MK, Alam MR, Arefin MS (2011) Biochemical studies of juice quality and yield performance of some promising sugarcane clones under water-logging stress condition. J. Agrofor. Environ. 5 (1): 87-90.

Jaffe' WR (2012) Health effects of non-centrifugal sugar (NCS): a review. Sugar Tech. 14(2):85-94.

Khaiyam MO, Islam MS, Ganapati RK, Uddin MJ, Hossain MI (2018) Suitability of newly released sugarcane varieties in farmers field condition under high ganges river floodplain of Bangladesh. Int J Plant Biol Res. 6(2): 1086.

Manohar CM, Xue J, Murayyan A, Neethirajan S, Shi J (2017) Antioxidant activity of polyphenols from Ontario grown onion varieties using pressurized low polarity water technology. J Funct Foods. 31:52-62. 
Meerod K, Weerawatanakorn M, Pansak W (2018) Impact of sugarcane juice clarification on physicochemical properties, some nutraceuticals and antioxidant activities of non-centrifugal sugar. Sugar Tech. 21(3):471-480.

Ministry of Agriculture and Cooperatives. 2018. Agri-Map Online. Bangkok, Thailand. (Thai version). $28 \mathrm{pp}$

Mozafar A (1993). Nitrogen fertilizers and the amount of vitamins in plants: A review. J. Plant Nutr. 16:2479-2506.

Nayaka MAH, Sathisha UV, Manohar MP, Chandrashekar KB, Dharmesh SM (2009) Cytopro- tective and antioxidant activity studies of jaggery sugar. J Food Chem 115(1): 113-8.

Noa M, Mas R (2005) Protective effect of policosanol on atherosclerotic plaque on aortas in monkeys. Arch Med Res. 36(5):441-447.

Nuissier G, Bourgeois P, Grignon-Dubois M, Pardon P, Lescure $\mathrm{MH}$ (2002) Composition of sugarcane waxes in rum factory wastes. Phytochemistry. 61(6):721-726.

Purcell DE, Leonard GJ, O'Shea MG, Kokot SA. (2005) Chemometrics investigation of sugarcane plant properties based on the molecular composition of epicuticular wax. Chemom. Intell. Lab. Syst. 76(2):135-147.

Payet B, Cheong AS, Smadja J (2005) Assessment of antioxidant activity of cane brown sugars by ABTS and DPPH radical scavenging assays: Determination of their polyphenolic and volatile constituents. J Agric Food Chem. 53(26):10074-10079.

Prasara-AJ, Gheewala SH (2016) Sustainability of sugarcane cultivation: case study of selected sites in north-eastern Thailand. Clean Prod. 134:613-622.

Pratt PF (1965) Potassium. In 'Methods of soil analysis, Part 2: chemical and microbiological properties. (American society of agronomy), Madison, Wisconsin. pp. 1023-1031.

Rhoades JD (1996) Salinity: electrical conductivity and total dis- solved salts. In: Methods of soil analysis. Part 3. Chemical methods. Sparks, D.L. ASA and SSSA: Wisconsin-Madison, U.S.A, pp. 417-435.

Simko P, Polovkov M (2017) Determination and occurrence of 5-hydroxymethyl-2-furaldehyde in white and brown sugar by high performance liquid chromatography. Food Control. 78: 183-186.

Singh DK, Li L, Porter TD (2006) Policosanol inhibits cholesterol synthesis in hepatoma cells by activation of AMP-kinase. J Pharmacol Exp Ther. 318(3):1020-1026.
Takahashi M, Ishmael M, Asikin Y, Hirose N, Mizu M, Shikanai T, Tamakiet H, Wada K (2016) Composition, taste, aroma, and antioxidant activity of solidified noncentrifugal brown sugars prepared from whole stalk and separated pith of sugarcane (Saccharum officinarum L). J Food Sci. 81(11):C2647-C2655.

Takara K, Kinjyo A, Matsui D, Wada K, Nakasone Y, Yogi S (2002) New antioxidative phenolic glycosides isolated from kokuto, non-centrifuged cane sugar. Biosci Biotechnol Biochem. 66(1):29-35.

Taylor JC, Rapport L, Lockwood GB (2003) Octacosanol in human health. Nutrition. 19(2):192-195.

Verschoyle RE, Greaves P, Cai H, Arndt B, Broggini M, D'Incalci $M$ (2006) Preliminary safety evaluation of the putative cancer chemo preventive agent tricin, a naturally occurring flavone. Cancer Chemother Pharmacol. 57(1):1-6.

Verschoyle RE, Greaves P, Cai H, Arndt B, Broggini M, D'Incalci M, Riccio Ed, Doppalapudi R, Kapetanovic IM, Steward WP, Gescher AJ (2006) Preliminary safety evaluation of the putative cancer chemo preventive agent tricin, a naturally occurring. Cancer Chemother Pharmacol. 57(1):1-6.

Weerawatanakorn M, Asikin Y, Takahashi M, Tamaki H, Wada K, Ho CT, Chuekittisak R (2016) Physico-chemical properties, wax composition, aroma profiles, and antioxidant activity of granulated non-centrifugal sugars from sugarcane cultivars of Thailand. J of Food Sci Technol. 53(11):4084-4092.

Walkley A, Black IA (1934) An examination of degtjareff method for determining soil organic matter and a proposed modification of the chromic acid titration method. Soil Sci. 37(1):29-37.

Weerawatanakorn M, Tamaki H, Asikin Y, Wada K, Takahashi M, Ho CT (2017) Policosanol contents, volatile profile and toxicity test of granulated cane sugar enriched with rice bran materials. Int Food Res. 24(3):1019-1028.

Zambrosi FCB, Ribeiro RV, Marchiori PE, Cantarella $\mathrm{H}$, Landell MGA (2014) Sugarcane performance under phosphorus deficiency: physiological responses and genotypic variation. Plant and Soi. 386(1): 273-283.

Zhao X, Carey EE, Wang W, and Rajashekar CB (2006) Does organic production enhance phytochemical content of fruit and vegetables? Current knowledge and prospects for research. Horttechnology. 16(3): 449-456 